Anais da Academia Brasileira de Ciências (2006) 78(3): 607-614

(Annals of the Brazilian Academy of Sciences)

ISSN 0001-3765

www.scielo.br/aabc

\title{
Shallow gas accumulation in sediments of the Patos Lagoon, Southern Brazil
}

\author{
JAIR WESCHENFELDER ${ }^{1}$, IRAN C.S. CORRÊA ${ }^{1}$, SALVADOR ALIOTTA ${ }^{2}$, \\ CARLA M. PEREIRA ${ }^{1}$ and VINICIUS E.B. DE VASCONCELLOS ${ }^{1}$ \\ ${ }^{1}$ Instituto de Geociências, Universidade Federal do Rio Grande do Sul \\ Cx. Postal 15.001, 91501-970 Porto Alegre, RS, Brasil \\ ${ }^{2}$ Instituto Argentino de Oceanografia Complejo CRIBABB \\ Camino Carindanga km 7, 8000 Bahia Blanca, Argentina \\ Manuscript received on March 31, 2005; accepted for publication on March 10, 2006; \\ presented by LAURO V.S. NARDI
}

\begin{abstract}
A high resolution seismic survey was conducted in the Patos Lagoon, southern Brazil, aboard of the research vessel LARUS of the Fundação Universidade Federal do Rio Grande (FURG). Around $400 \mathrm{~km}$ of $3.5 \mathrm{kHz}$ seismic profiles were collected, which provided acoustic signals of good penetration depth and resolution. Seismic anomalies, including turbidity and pocket gas, revealed that gas-charged sediments are common in several areas of the lagoon. The gas accumulations in the Patos Lagoon are controlled by the spatial distribution of the sedimentary facies. Either in 'curtains' or in 'acoustic turbid zones', the main gas accumulations occur in areas with paleotopographic lows related to fluvial channels and valleys developed in the Rio Grande do Sul coastal plain during regressive/transgressive events of the Quaternary.
\end{abstract}

Key words: shallow gas, $3.5 \mathrm{kHz}$ seismic, coastal plain, Rio Grande do Sul.

\section{INTRODUCTION}

Seismic survey undertaken in the last decades has helped detecting gas concentration in recent deposits located in several coastal environments around the world (Garcia-Garcia et al. 1999, Karisiddaiah et al. 1992, Papatheodorou et al. 1993, Park et al. 1991). For the particular case of the South America Atlantic coast, gas occurrences have been reported in the Rio de La Plata estuary (Parker and Paterlini 1990), in the inner section of the San Matias Gulf (Aliotta et al. 2000) and in the Bahía Blanca estuary (Aliotta et al. 2002). In Brazil, gas in sediments has been detected in the Guanabara Bay in the State of Rio de Janeiro (Baptista Neto et

Correspondence to: Prof. Jair Weschenfelder

E-mail: jair.weschenfelder@ufrgs.br al. 1996, Quaresma et al. 2000), and in shallow parts of the Amazonas Continental Shelf (Costa and Figueiredo 1998, Figueiredo et al. 1996).

Shallow seismic survey undertaken in Quaternary sediments from the Patos Lagoon revealed acoustic anomalies that were related to gas occurrences. The purpose of this study is to characterize these anomalies, providing new elements to understand the mode of gas formation within the context of geological evolution of this coastal plain.

\section{STUDY AREA}

The Patos Lagoon is located in the coastal zone of the State of Rio Grande do Sul (RS), southern Brazil (Fig. 1). This area represents the upper part of the Pelotas Basin, which is one of the several 
sedimentary basins situated along the Brazilian continental margin. The evolution of these basins is related to crustal rupture of the Western Gondwana landmass and subsequent formation of the South Atlantic Ocean. Seismic data of the upper slope of the Pelotas Basin indicate a sedimentary package more than $10 \mathrm{~km}$ thick, consisting mostly of shales, sandstones, carbonates and conglomerates, deposited from Late Mesozoic to Recent.

The coastal zone of RS is characterized by wide lowlands throughout an area of around $33,000 \mathrm{~km}^{2}$, bounded by highlands to the west and the Atlantic Ocean to the east. It is one of the widest coastal plains of the world.

The Patos Lagoon, with its approximately $10,000 \mathrm{~km}^{2}$, is a remarkable feature in the physiography of the coastal plain of RS. The lagoon, $240 \mathrm{~km}$ long (NE-SW) and averaging $40 \mathrm{~km}$ wide, receives an enormous river discharge from a huge drainage area and leads it to the Atlantic Ocean through a single inlet - the Rio Grande Channel located near the city of Rio Grande, at the southernmost part of the lagoon. Sandy spits represent a remarkable feature that extends several kilometers from the margin into the center areas of the lagoon. On the west side of the lagoon, the submerged part of these spits extends up to $15 \mathrm{~km}$ (Toldo et al. 2000).

Studies on sedimentation, wave pattern and dynamics in the Patos Lagoon were presented by Toldo-Jr (E.E. Toldo-Jr., unpublished data) and Toldo-Jr et al. (2000). According to these two works, the lagoon is a large and shallow (average depth of $6 \mathrm{~m}$ ) coastal water body, not much influenced by the astronomic tides $(<45 \mathrm{~cm})$, and protected from an environment dominated by waves of the nearby ocean. Moreover, Toldo-Jr et al. (2000), based on several morphological and sedimentological criteria, established two distinct areas in the Patos Lagoon: 1) a sandy margin, and 2) a flat and muddy center. Depths ranging between 5 and $6 \mathrm{~m}$ separate both areas. The muddy area represents approximately up to $40 \%$ of the lagoon. The bottom and margins of the lagoon are subject to the influence of waves, which may reach up to $1.6 \mathrm{~m}$ high.

Upper Quaternary sea level changes were the main process responsible for sediment evolution in the Patos Lagoon. The deposits, which alternate basically coastal-barrier sands and lagoonal silts and clays, have been related to four phases of a lagoonbarrier depositional system (Villwock et al. 1986). The sandy packages may form aquifers and/or gas reservoirs, while the finer, mainly muddy sediments may form aquitards and/or sealing layers.

\section{METHODOLOGY OF SEISMIC DATA ACQUISITION}

Approximately $400 \mathrm{~km}$ of high-resolution seismic profiles were recorded inside the Patos Lagoon (Fig. 1), a task performed aboard of the LARUS, the research vessel of the Fundação Universidade Federal do Rio Grande (FURG). The position of ship routes and seismic profiles was determined by a differential global position system (DGPS).

The seismic data were obtained with a GeoAcoustics subbottom profiler system, operating at $3.5 \mathrm{kHz}$ frequency, and consisting of a Geopulse 5430A transmitter, a Geopulse 5210A receiver, a Geopulse 132B 4-mount transducer array, an EPC GSP 1086 graphic recorder, a GeoPro processor system, and a Sonarwiz seismic data acquisition software. The transducer was mounted on the outer side of the hull of the LARUS and it served simultaneously as sender and receiver of the acoustic signal. The seismic dataset was saved in analogical and SEG-Y digital formats. The profiles are presented with depths to water surface in two-way traveltime, in milliseconds (ms). An average estimated acoustic velocity of $1650 \mathrm{~m} / \mathrm{s}$ was used to calculate the thickness of the sedimentary packages.

\section{RESULTS}

Anomalous acoustic responses in seismic data allowed the identification and mapping of shallow gas accumulations in the Patos Lagoon area. These are recorded as gas curtain and acoustic turbid zone. Depending on the gas concentration in the 


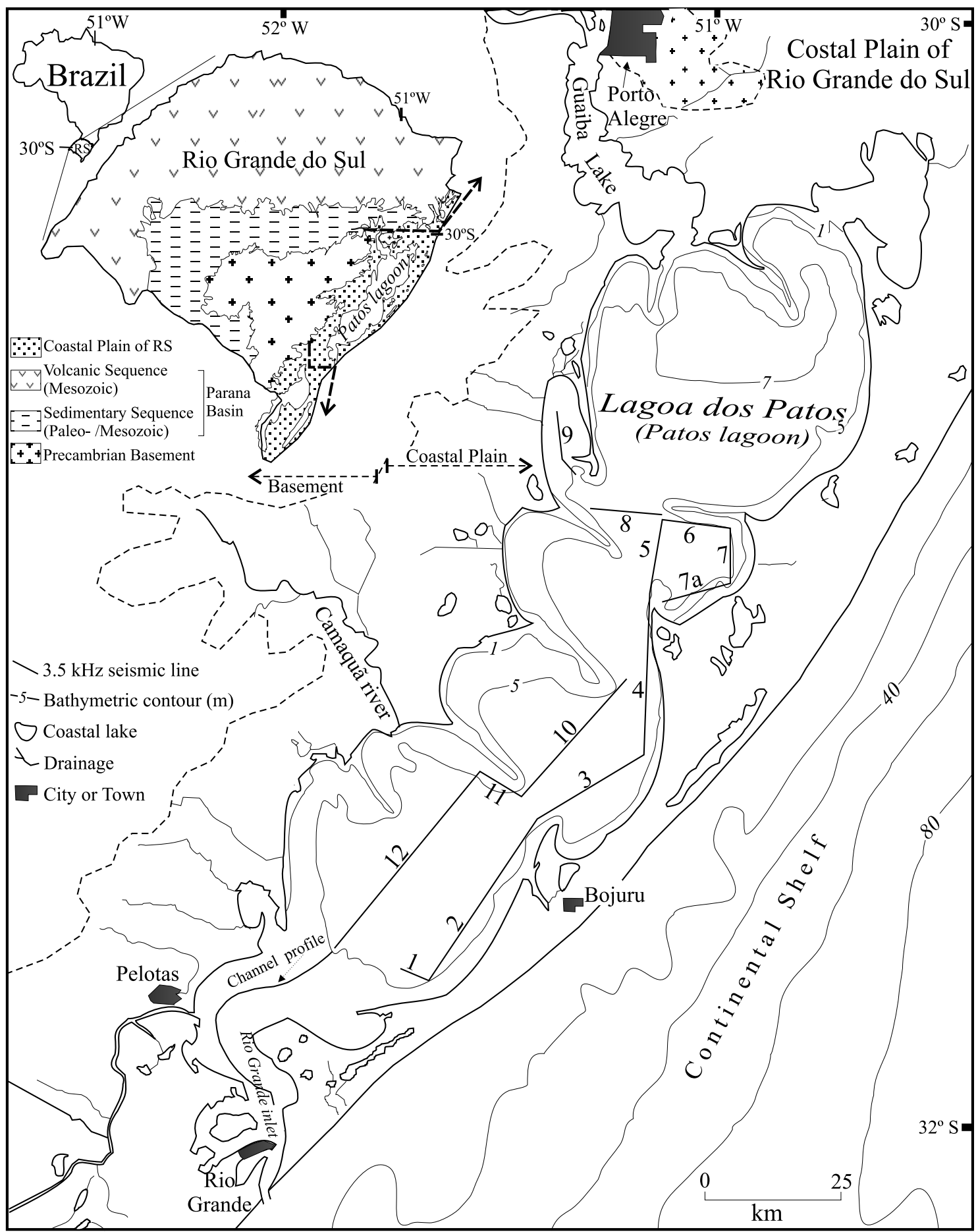

Fig. 1 - Location map of the area of study and position of the $3.5 \mathrm{kHz}$ seismic lines 1-12 mapped in the Patos Lagoon. 
sediments, there may be some gradation between these two types or even a gradual or sudden change to sections apparently without gas.

Gas curtain - this type of gas accumulation usually shows a well defined morphology, in the form of 'boxes' of anomalous seismic reflection with an upper surface well marked by strong, relatively continuous, horizontal or gently dipping top reflectors. The acoustic response below the top reflectors is usually chaotic, masking the underlying sedimentary structures. Gas curtains range from a few meters to several kilometers laterally (Fig. 2a). Sidewards, the strong top reflector is sometimes suddenly interrupted, forming 'acoustic windows' (Fig. 2b). When several acoustic windows are present in the seismic records the lateral continuity of the seismic reflectors can be established, as well as the internal structure of the sedimentary units. The gas curtains are usually interspersed with acoustic windows. Like gas curtains, acoustic windows range from just a few meters to several kilometers wide.

Acoustic turbid zone - this is a type of gas accumulation in which the acoustic anomaly is characterized by a more irregular and less marked top reflector than zones with gas curtains. The seismic reflectors underlying the top of the gas accumulation are not entirely hidden, allowing the identification and mapping of the sedimentary structures (Fig. 2c and d).

Similarly to gas curtains, acoustic turbid zones can also range from a few meters to several kilometers laterally. The upper surfaces of these gas accumulations are diffuse, sometimes reaching the bottom of the lagoon (Fig. 2c). The gradual transition from acoustic turbid zones to gas curtains or to zones without gas was observed in some seismic sections.

Distribution of Shallow Gas IN THE PATOS LAGOON

Acoustic gas anomalies have been identified in all seismic sections of the Patos Lagoon, being more frequent in inner areas of the lagoon (e.g., profiles
3, 5, 10 and 12) than marginwards (e.g., profiles 1 , 2, 6 and 7) (Fig. 1).

Gas curtains occur mainly in the central part of the lagoon, usually where the configuration of the seismic reflectors indicates paleotopographic depressions. For instance, the two big gas accumulations seen in profile 12 occur within depression separated by paleotopographic highs delineated by strong seismic reflectors (Fig. 3). In this section, the northeastermost gas curtain, which occurs in front of the present mouth of the Camaquã River, is well-defined by a big ( $\sim 7 \mathrm{~km}$ wide), continuous 'gas box' displaying a upper surface marked by a strong reflector (Fig. 3, left side). However, the southwestermost gas curtain shows a top marked by a diffuse reflector. In addition, this gas curtain grades laterally to an acoustic turbid zone and, southwestwards, to a zone with minor quantities of gas or even gas free (Fig. 3, right side).

Acoustic turbid zones occur in several of the mapped seismic profiles. It is a gas accumulation usual at the border of pocket gas, at marginal sections of the lagoon and in sedimentary packages elsewhere.

\section{DISCUSSION}

High-frequency seismic profiles mapped inside the Patos Lagoon show anomalous acoustic configurations commonly attributed as typical for sediments loaded with gas (Judd and Hovland 1992, Hart and Hamilton 1993, Figueiredo et al. 1996).

The presence of gas in sediments is detected especially by high-resolution seismic profiling due to the change of speed of the acoustic wave between mediums with and without gas. The higher the speed gradient between the mediums, the stronger the echo response generated by the variation of acoustic impedance between them. The intensity of the reflected acoustic signal recorded in the seismic profiles can be related to the concentration of gas bubbles in the sediments (Aliotta et al. 2002).

Seismic responses observed in gas accumulations are related to the amount of gas concentrate in 

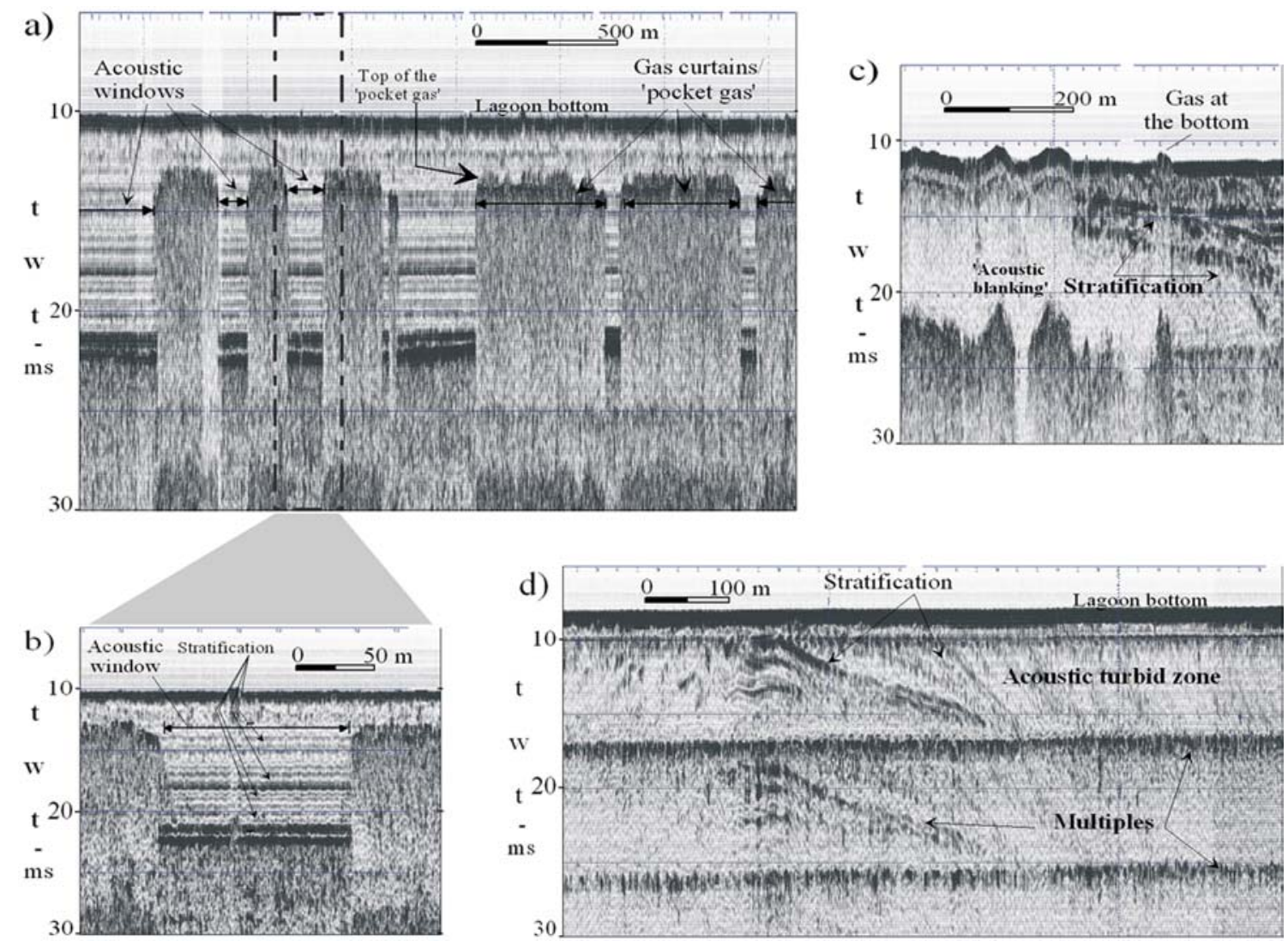

Fig. 2 - Acoustic anomalies from seismic line 4 (see Fig. 1 for location): a) intercalation of 'gas curtains' with 'acoustic windows'; b) zoom of the dashed part of figure 2a; c) record with 'acoustic blanking' and gas at the lagoon bottom; d) detail of an 'acoustic turbid zone' showing sedimentary stratification. Depths to water surface in two-way traveltime, in milliseconds (ms).

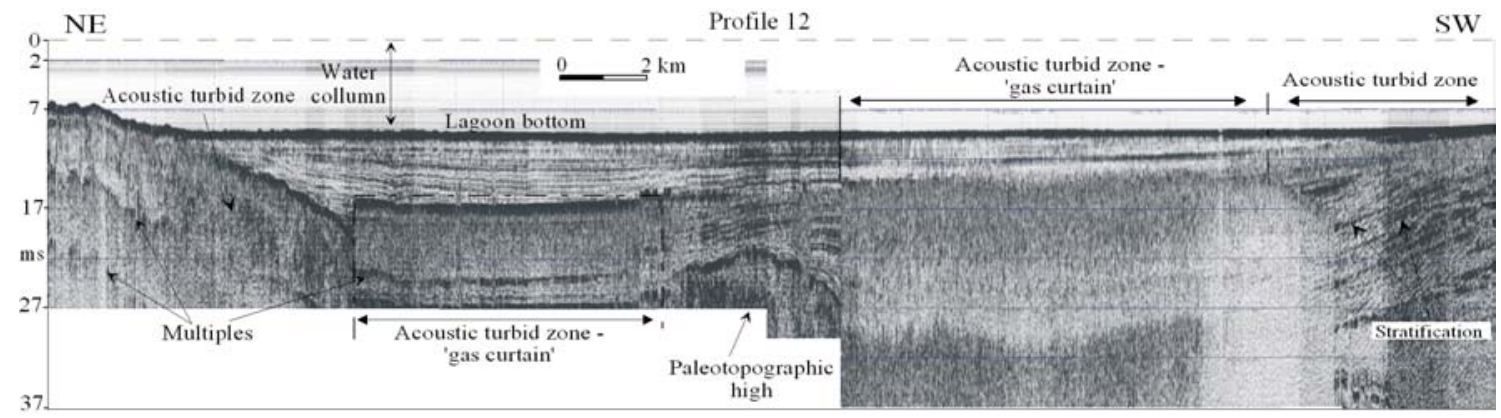

Fig. 3 - Linkage of gas occurrences to areas of paleotopographic lows in profile 12 (see Fig. 1 for location). Depths to water surface in two-way traveltime, in milliseconds (ms).

the sedimentary package. Hence, 'acoustic turbidity' zones occur where the presence of gas causes a strong reflection at the top of the gassy package, usually masking deeper reflectors. This phenome- non is caused by diffusion of acoustic energy due to gas bubbles trapped in the sediments (Hart and Hamilton 1993). The increasing contrast of the acoustic speed between zones with and without 
gas causes the phenomenon known as 'gas brightening' (Hart and Hamilton 1993). 'Acoustic blanking' anomalies were observed in some segments of the seismic records (Fig. 2c). In this acoustic phenomenon, seismic reflections below the gas horizon are very weak or absent due the attenuation of the acoustic signal (Judd and Hovland 1992).

In the Patos Lagoon, the sections with gas curtains correspond to higher gas concentrations in relation to acoustic turbid zones. The morphology of 'gas curtains' is attributed to the presence of 'pocket gas' in the sedimentary package. As a result, there is a strong reflection and then dispersion of the seismic wave, hiding possible reflectors underlying the strong top reflector of the gas curtains. However, in acoustic turbid zones, the gas concentrations are smaller, allowing a certain degree of penetration of the seismic energy. The seismic reflectors underlying the top of the package with less quantities of gas are only partially hidden. Hence, mapping of sediment architectural patterns in the Patos Lagoon can be performed where acoustic turbid zones are present, as well as in the many and wide acoustic windows usually occurring interspersed with gas curtains and/or turbid zone morphologies.

Seismic mapping has led to the identification of palevalleys and paleochannels in the Patos Lagoon (J. Weschenfelder, unpublished data). Close spatial association of gas occurrences and paleotopographic lows caused by fluvial incision in the RS coastal plain was suggested by Weschenfelder et al. (2005a, b).

Sectors of the seismic records representing areas of paleotopographic depressions and areas of former deltaic environments are the places showing the most important gas accumulations. Some of these paleotopographic lows can be linked to former river courses (e.g., the Camaquã River) that dissected the costal plain of RS when sea level was much lower than today (Corrêa 1996). The sedimentary fill of these incised channels and valleys is related to sedimentary processes of subsequent transgressive events (Weschenfelder et al. 2005b).
The paleotopographic high delineated by the seismic reflectors in the middle of profile 12 has been interpreted as sedimentary in origin (J. Weschenfelder, unpublished data). It should be interpreted as a paleospit, as it resembles the modern sandy spits that extend from the margin to the center of the lagoon.

Biogenic degradation of organic matter in sediments is reported by Kaplan (1974) as a main source of gas in marine sediments. The gas accumulations mapped in the Patos Lagoon are shallow and occur in a dominantly fine-grained sedimentary package deposited during the Quaternary. This suggests that the gas concentrations might have originated from the degradation of organic matter deposited in the paleoenvironments developed there. Thus, the source of gas and the accumulation mode are intimately related to the sedimentary environments and to the evolutionary processes responsible for the formation of the vast coastal water body of the Patos Lagoon.

The acoustic windows in the seismic records of the Patos Lagoon occur due to an abrupt lateral discontinuity in some seismic horizons related to gas. They may suggest either an absence of organic matter for generating gas or the lack of a trapping layer (Costa and Figueiredo 1998, Figueiredo et al. 1996).

Geological studies are currently been conducted in the Patos Lagoon in order to identify the degree of control exerted by the distribution of the sedimentary facies, permeability of the sedimentary layers and original amount of organic matter on gas accumulations. The present work contributes with these studies by characterizing the gas accumulation of this area.

\section{CONCLUSIONS}

The presence of shallow gas in sediments of the Patos Lagoon has a significant effect on the geoacoustic behavior of the sedimentary package. The gas accumulations can be clearly identified in highresolution $(3.5 \mathrm{kHz})$ seismic data through acous- 
tic anomalies detected as anomalous seismic reflections. Sectors with 'gas curtains' and 'acoustic turbid zones' can be differentiated through such anomalies. In some seismic sections, sectors of acoustic anomalies intersperse with acoustic windows, and represent packages with gas alternating with packages without gas, respectively.

Gas accumulations in the Patos Lagoon are controlled by the spatial distribution of the sedimentary facies. Either in 'curtains' or in 'acoustic turbid zones', the gas occurs mainly in inner zones of the lagoon, almost always associated with areas displaying low paleotopography, related to paleodrainage systems. Such drainage systems, represented by fluvial channels and valleys, were probably formed during low sea level episodes. Depressions caused by such fluvial incisions were drowned and filled up by sediments during a subsequent transgression.

The shallow gas in the Patos Lagoon substrate is intimately linked to sedimentary environments and to the evolution of the Rio Grande do Sul coastal system as result of Quaternary sea level fluctuation.

\section{RESUMO}

Um levantamento sísmico de alta resolução foi realizado na Lagoa dos Patos, sul do Brasil, a bordo da Lancha Oceanográfica Larus da Fundação Universidade Federal do Rio Grande (FURG). Foram levantados aproximadamente $400 \mathrm{~km}$ de perfis de $3,5 \mathrm{kHz}$, os quais apresentaram uma resposta acústica de boa penetração e resolução. Anomalias sísmicas, incluindo turbidez acústica e bolsões de gás, revelam que sedimentos carregados de gás são comuns em diversas áreas do corpo lagunar. As acumulações de gás na Lagoa dos Patos são controladas pela distribuição espacial das fácies sedimentares. Tanto as acumulações de gás na forma de 'cortinas', como as 'zonas acusticamente turvas', ocorrem em área de baixios paleotopográficos, vinculados a vales e canais fluviais que se desenvolveram na planície costeira do Rio Grande do Sul durante os eventos regressivos/transgressivos do Quaternário.
Palavras-chave: gás raso, sísmica de $3,5 \mathrm{kHz}$, planície costeira, Rio Grande do Sul.

\section{REFERENCES}

Aliotta S, Kostadinoff J and Lizasoain G. 2000. Sísmica somera com $3.5 \mathrm{kHz}$ de la Plataforma Continental norpatagónica, Argentina. In: II CONGRESSO LATINOAMERICANO DE SEDIMENTOLogía. Mar del Plata, Argentina. Resúmenes, p. $26-27$

Aliotta S, Lizasoain G and Ginsberg S. 2002. Hallazgo de acumulaciones de gas con sismica de alta resolucion en sedimentos del estuario de Bahia Blana, Argentina. In: CABAleri N ET AL. (Eds), Actas del XV Congresso Geológico Argentino (CDROM) 146: 315-318.

BAptista Neto JA, Silva MAM AND Figueiredo JR AG. 1996. Sísmica de alta freqüência e o padrão de distribuição de sedimentos na enseada de Jurujuba (Baía de Guanabara) - RJ/Brasil. Rev Bras Geof 14: 51-57.

CORRÊA ICS. 1996. Les variations du niveau de la mer durant les derniers 17.500 ans BP. L'exemple da la plateforme continentale du Rio Grande do Sul - Bresil. Mar Geol 130: 163-178.

Costa EA And Figueiredo AG. 1998. Echo-character and sedimentary processes on the Amazon Continental Shelf. An Acad Bras Cienc 70: 187-200.

Figueiredo AG, Nittrouer CA And Costa EA. 1996. Gas-charged sediments in the Amazon Submarine Delta. Geo-Marine Letters 16: 31-35.

Garcia-Garcia A, Vilas F and Garcia-Gil S. 1999. A seeping sea-floor in Ria environment: Ria de Vigo (Spain). Envir Geol 38: 296-300.

HART BS AND HAMILTON TS. 1993. High resolution acoustic mapping of shallow gas in unconsolidated sediments beneath the Strait of Georgia, British Columbia. Geo-Marine Letters 13: 49-55.

JudD AG AND Hovland M. 1992. The evidence of shallow gas in marine sediments. Cont Shelf Res 12: 1081-1096.

KAPLAN IR. 1974. Introduction. In: KAPLAN IR (Ed), Natural gases in Marine Sediments. Planum Press, New York, USA, p. 1-10.

KARISIDDAIAH SM, VEERAYYA M, VORA KH AND WAGLE BG. 1992. Gas-charged sediments on the 
inner continental shelf off western India. Mar Geol 110: $143-152$.

Papatheodorou G, Hasiotis T and Ferentinos G. 1993. Gas-charged sediments in the Aegean and Ionian Seas, Greece. Mar Geol 112: 171-184.

PARK SC, KIM YS AND HoNG SK. 1991. Shallow seismic stratigraphy and distribution pattern of late Quaternary sediments in a macrotidal bay, Gunhung Bay, west coast of Korea. Mar Geol 98: 135-144.

PARKer G ANd PATerlini M. 1990. Apantallamientos acústicos en sedimentos gasíferos del Rio de La Plata. Rev Asoc Geol Argent 45: 17-28.

QUARESMA VS, Dias GTM AND BAPTISTA Neto JA. 2000. Caracterização da ocorrência de padrões de sonar de varredura lateral e sísmica de alta freqüência $(3,5$ e 7,0 kHz) na porção sul da Baía de Guanabara-RJ. Rev Bras Geof 18: 201-214.

Toldo Jr EE, Dillenburg SR, CorrêA ICS AND ALMEIDA LESB. 2000. Holocene sedimentation in Lagoa dos Patos lagoon, Rio Grande do Sul, Brazil. J Coast Res 16: 816-822.
Villwock JA, Tomazelli LJ, Loss EL, DeHNHARDT EA, HORN FILHO NO, BACHI FA AND DEHnhardT BA. 1986. Geology of the Rio Grande do Sul Coastal Province. Quaternary of South America and Antarctic Península 4: 79-97.

Weschenfelder J, Corrêa ICS, Ayup-Zouain RN, Aliotta A, Pereira CM and VasconCELLOS VEB. 2005a. Gas accumulations revealed by high-resolution seismics in the Patos Lagoon, southern Brazil. In: VIII INTERNATIONAL CONFERENCE on Gas in MARINE SEdiments. Vigo, Spain, $133 \mathrm{p}$.

Weschenfelder J, Medeanic S, Corrêa ICS, Aliotta S, Pereira CM And Vasconcellos VEB. 2005b. Holocene paleoenvironmental changes in the Bojuru region, RS, Brazil: a multidisciplinary approach. In: X CONGRESSO DA ABEQUA. Guarapari, ES, Brazil, 6 p. 